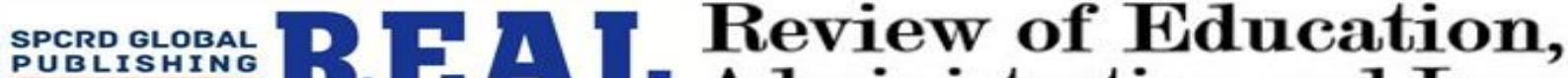 Administration and Law
}

Journal homepage: http://real.spcrd.org ISSN (Print): 2708-1788

ISSN (Online): 2708-3667

\section{An Econometric Investigation of Sectoral Output and Environmental Degradation in Pakistan}

\author{
${ }^{a}$ Furrukh Bashir, ${ }^{\mathrm{b}}$ Imran Sharif Chaudhry, ${ }^{\mathrm{c}}$ Rashid Ahmad, ${ }^{\mathrm{d}}$ Fiza Habib \\ ${ }^{a}$ Assistant Professor, School of Economics, Bahauddin Zakariya University, Multan, Pakistan \\ Email: furrukh@bzu.edu.pk \\ ${ }^{\mathrm{b}}$ Dean, Faculty of Arts - Social Sciences, Bahauddin Zakariya University, Multan, Pakistan \\ Email:imran@bzu.edu.pk \\ ${ }^{c}$ Assistant Professor, School of Economics, Bahauddin Zakariya University, Multan, Pakistan \\ Email: rashidahmad@bzu.edu.pk \\ ${ }^{\mathrm{d}}$ M. Phil. Scholar of Economics, Bahauddin Zakariya University, Multan, Pakistan
}

\begin{tabular}{l} 
ARTICLE DETAILS \\
\hline History: \\
Accepted 12 Nov 2020 \\
Available Online 31 Dec 2020 \\
\hline Keywords: \\
Carbon Dioxide Emission, \\
Agriculture Sector Output, \\
Industry Sector Output, Services \\
Sector Output, Exports, Energy
\end{tabular}

JEL Classification:

F64, O13, L69, O14, Q56, O13, $\mathrm{P}_{2} 8, \mathrm{P}_{4} 8$

DOI: $10.47067 /$ real.v3i3.

\begin{abstract}
This study examines the effect of sectoral output (agriculture, industry, and services) on environmental degradation in Pakistan ranging from the period 1972 to 2017. This study makes use of the Augmented DickeyFuller test $(A D F)$ followed by the Autoregressive distributed lag model (ARDL). The empirical results show that Co2 emission in Pakistan is increased by Industrial sector output, population, and energy consumption while agriculture sector output, services sector output, and exports are reducing carbon dioxide emission. Moreover, it is suggested that Pakistan needs to make its industry sustainable by replacing the old capital stock with new and energy-efficient capital. It is favorable to replace less efficient technologies with environmental-friendly technologies to make the production process less polluting.
\end{abstract}

(C) 2020 The authors. Published by SPCRD Global Publishing. This is an open access article under the Creative Commons Attribution-

NonCommercial 4.0

Corresponding author's email address: furrukh@bzu.edu.pk

\section{Introduction}

Environmental problems are considered in the map of economic policy since the mid-1980s. Natural resources are an important input in the production process (Costantini and Monni, 2006). The use of these natural resources has several impacts on the environment depending upon their usage. Change in atmospheric temperature usually known as global warming has gained attention due to its increasing intensity with each passing year. Rise in world air temperatures on average and melting of snow and ice are a few confirmations of a dangerous atmospheric temperature deviation. Global warming is caused due to the emissions of Green House Gases (GHG) which include water vapors, carbon dioxide, methane, and nitrous oxide, and manmade gases that are used for aerosols.

Environmental topics in economic growth theories have been in the limelight in the literature 
recently. Most of the economists and environmentalists ponder on the fact that what contribution does output growth have in increasing environmental degradation. According to the current research, a rapidly growing economy causes more carbon dioxide emission instigating from developing countries (Asumadu- Sarkodie \& Owusu, 2016a, 2016c, and 2016d). The effects of environmental degradation on human health are enormous and its hazards are causing social issues (Asumadu-Sarkodie \& Owusu, 2016b, and 2016e). Biodegradation has a significant effect on the occurrence of natural disasters and their intensity which leads to a fall in economic growth. (Azam, Khan, Abdullah, \& Qureshi, 2016).

Pakistan is one of the affected countries by environmental change issues and has been positioned the seventh position among the most antagonistically influenced nations, the reason being global warming. Among crucial steps taken to control the GHG emissions, the Kyoto Protocol emerged due to Global warming, desertification, and deforestation, and its substantial impact on health. After its dissemination in 1997, the Kyoto Protocol has 84 Signatories and 193 Parties including Pakistan. The target of the Kyoto Protocol is to lessen emissions of GHG and other polluted gases under the United Nations Framework Convention on Climate Change. It elevates and creates rules to facilitate endeavors to lessen the disturbing dimensions of an unnatural weather change and to conquer the related issues. Besides, the convention proposes the fact that highly industrialized nations which are including 37 European communities which need to reduce their total emissions by 0.5 percent. Pakistan has likewise marked the climate change convention in 1992 and has endorsed the Protocol in 2005(GOP, 2003).

Table 1 shows the decade vise situation of Pakistan in terms of Sectoral Growth, Environmental Degradation, and few other variables used in this study. This table illustrates that agriculture sector growth was increasing till the 1990 s but after this, it is declining as 2.09 percent. On the other side, industrial sector growth was maximum in the 1970s but after that, it starts declining up to 1990 s decade. In the 2000s, it increased slightly and then again declines in the 2010 s decade. Considering Services sector growth, it is seen that from the 1970s to 2010s, this sector is continuously declining in Pakistan.

Talking about Growth of Exports, Pakistani export was increased in the 1980 s and then declined in 1990s, then again it increased in the 2000s and 2010s decade, it was minimum. Similarly, the growth of energy is also being reduced in Pakistan during these decades. The population growth rate is declining in Pakistan from the 1970s to the 2010 s decades. Carbon Dioxide Emission growth has also reduced in Pakistan as evident from table 1.

Table 1: Average growth rate (decade wise analysis)

\begin{tabular}{|c|c|c|c|c|c|}
\hline Variable & 1970's & 1980's & 1990's & 2000's & 2010's \\
\hline Agriculture sector growth & 2.91 & 4.07 & 4.54 & 2.62 & 2.09 \\
\hline Industry sector growth & 7.06 & 6.62 & 4.50 & 4.90 & 4.60 \\
\hline Services Sector Growth & 7.06 & 7.76 & 4.19 & 5.80 & 4.03 \\
\hline Growth of Exports & 5.27 & 8.82 & 5.15 & 7.78 & 1.94 \\
\hline Growth of energy use & 1.35 & 2.32 & 1.51 & 0.78 & 0.58 \\
\hline Population growth & 3.18 & 3.10 & 2.24 & 2.25 & 2.00 \\
\hline CO2 emission growth & 6.88 & 7.92 & 4.57 & 4.31 & 0.77 \\
\hline
\end{tabular}

The increasing focus on the growth nexus has compelled us to divert our attention to the externalities offered along with the growing economy. Environmental degradation has been quiet in discussion for a few years. There are many indicators used as proxies for environmental degradation most important being the resource footprints including Sulphur dioxide $\left(\mathrm{So}_{2}\right)$, carbon dioxide $\left(\mathrm{Co}_{2}\right)$, 
nitrogen oxides, etc. A valid concern is the carbon dioxide delivered from non-renewable energy sources (fossil fuels). Carbon dioxide levels in the air are rising and raising the temperature of Earth, which undermines wide environmental change. This is the reason that Carbon dioxide is used in the majority of studies as an indicator of environmental degradation.

Although this theme of research isn't broadly utilized in the scholarly and research field, the present investigation follows the sequential sensible illustration from past examinations and utilize new factors and their combinations which were not engaged previously. These include sectoral growth (agriculture, industry, and services sectors) along with some other variables which are total population, exports, and energy use. The objective of this study is to check the impact of Sectoral Growth (Agriculture, Industry and Services Sector) on Environmental Degradation in Pakistan.

\section{Literature Review}

The issue of environmental degradation with economic growth has been in discussion by many socio-economists and environmentalists as well. Vast writing is accessible on the attempted issue at national and international dimensions that are associated with various developed, developing and underdeveloped countries.

Ecological modernization theory attempted to shed some light upon the fact that in what way do the different institutions and social sectors incorporate concerns related to the environment into their daily working leading to the development and their relationship with the outer world (Mol et al., 20o9). This theory is based on an old concept discussed in environmental economics which says that the growth of income has a damaging impact on the environment but further it argues that income growth is capable of reduction of this damage in issues like these (Grossman and Krueger, 1991). Moreover, amid prior phase or times of economic development, environmental damage rises, however as development achieve a specific position, the community starts giving more importance to the natural environment which reduces the damage caused.

The phenomenon of the EKC hypothesis gives a summary of the dynamically changing process. But it does not give any clear indication of the time frame. The impact of Economic growth can be explained in three different ways: technological effect, composition effect, and scale effect (Grossman and Krueger, 1991). Scale effect, exhibited by the economic growth has an inverse relationship with the environment which can be observed by the fact that to increase the output produced, more natural resources have to be used which ultimately contributes to increasing the waste and emission of harm full gases, resultantly worsening the damage to the environment. On the other hand, the composition effect leads the economic growth to have a direct impact on the environment: it happens as a consequence of the changing structure of the economy and the transition towards a cleaner environment due to increment in the incomes of the people. As the nation becomes wealthy, it becomes able to promote the R\&D (research \& development) activities easily by spending more in this sector (Komen et al 1997) which compels to believe that with economic growth leading it's way higher, technology improves in the respective nation due to which the tattered machines could be replaced by latest technology utilizing machinery; ultimately improving the environment. This fact gives the technique effect of economic growth. It is suggested by the EKC phenomenon that the direct impact of composition effect along with technique effects out weights the impact of scale effect which is negative and is prevalent in the initial stages of growth which lowers the emissions of the polluting gases (Vukina et al 1999)

The Environmental Kuznets Curve display has evoked clashing responses commencing from specialists and the policymakers. There are multiple factors from the context of economic development 
that govern the shape of the Environmental Kuznets Curve. Proper insight and attention are needed to analyze those factors rather than focusing on a single factor (Ezzati et al, 2001). The interdependency of these factors makes it hard to agree on the most important factor which governs the shape of the curve. This analysis of the EKC hypothesis is thus to be cautious of due to some deficiencies it offers.

Munir and Khan (2014) checked what impact does energy consumed by fossil fuel has on $\mathrm{Co}_{2}$ emissions for the country of Pakistan. Long-term results were estimated using Johanson co-integration approach while the short-run relationship was verified using the Vector Error Correction model. Various variables were used during the analysis such as industrial value growth, financial development, energy consumption by fossil fuels, GDP, GDPSQ, and trade openness. The results concluded the presence of a positive relationship between industrial value growth, fossil fuel consumption, GDP, trade openness, and carbon dioxide emissions while an inverse relationship between financial development, GDP square, and carbon dioxide emissions. The study recommended that Pakistan needed to devise a broad scope of environmental strategies that would give impetuses to industries to take on innovations, which could assist in lessening the environmental contamination.

Cole and Neumayer (2004) investigated the question that how do demographic factors impact air pollution. The research was carried out using two pollutants i.e. carbon dioxide $\left(\mathrm{Co}_{2}\right)$ and sulfur dioxide $\left(\mathrm{So}_{2}\right)$. The $\mathrm{Co}_{2}$ sample covered 86 countries using data for 24 years (1975 to 1998) while the $\mathrm{So}_{2}$ sample covered 54 countries using data for 20 years (1971-1990). The study used ordinary least squares (OLS) and panel-corrected standard errors to estimate the long term results. Variables used in the study

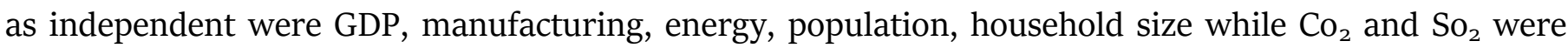
used as a dependant. The estimation results showed a positive relationship of $\mathrm{Co}_{2}$ with GDP, energy, and population while a negative relationship with manufacturing and household size. The results suggested that for both pollutants an increasing share of global emissions will be accounted for by developing countries.

Kahuthu (2006) observed and analyzed the relationship between economic growth and environmental degradation globally for 84 countries. The analysis was made using panel data over the period from 1960 to 2000 . Long run estimates were made using the OLS method of estimation. To portray the effect of environmental degradation, Co2 emissions and deforestation were used as dependant variables while GDP per capita was used as an independent variable. The long-term results concluded in the confirmation of the EKC model in case of $\mathrm{CO}_{2}$ emissions moreover the high interaction of countries with the international markets increases the expectation of carbon dioxide emission and a faster process of deforestation.

Ang (2007) investigated the fundamental relationship between three factors i.e. energy consumption, output, and pollutant emissions (carbon dioxide emissions) in France. The research was carried out making use of data in time series over the time from 1960 to 2000 using co-integration analysis. Commercial energy use, the per capita real GDP, and its square were used as independent variables while the dependant variable used was carbon dioxide emissions. Results indicated that the higher the energy use higher $\mathrm{CO}_{2}$ emissions. Moreover, growth of output contributes to $\mathrm{Co}_{2}$ emissions and energy consumption to show causal links in the long run.

Ozcan (2013) checked the EKC hypothesis for the case of 12 Middle East countries over the period from 1990 to -2008 by employing panel data methods particularly panel cointegration and FMOLS methods. The variables used were energy consumption, GDP, and GDP square as independent whereas $\mathrm{CO}_{2}$ was used as a dependant variable. The study concluded by providing evidence favorable to five Middle East countries. Moreover, for UAE, Egypt, and Lebanon inverted U-shaped EKC was found 
whereas no association was established between $\mathrm{Co}_{2}$ emissions and real output for the other four countries included in the Middle East. It was suggested sustainable growth policies need to be arranged to reduce the rate of emissions of pollutants.

Acar and Tekce (2014) analyzed the relationship between economic development and industrial pollution in selected Mediterranean countries. The analysis used panel data over the period from 1971 2010. The technique used to calculate long term results were panel fixed-effects estimations. Two empirical models were used. Model 1 incorporated GDP per capita as an independent variable while model 2 incorporated Industry value-added, Trade, Population density, urban population, and Energy use as an independent variable. The dependant variable used was per capita industrial $\mathrm{Co}_{2}$ emissions for both the models used. The study resulted in the positive effect of industry, urbanization, population density, and energy while the negative effect of GDP in cubic form and positive in quadratic form.

Sbia et al. (2014) inspected the behavior of economic growth, electricity consumption, and urbanization to environmental degradation for the United Arab Emirates. The study used many variables such as real GDP, electricity consumption, urban population, and exports which were the independent variables while $\mathrm{Co}_{2}$ emissions were used as a dependant variable. The analysis concluded that EKC existed as GDP revealed a positive sign while GDP square varied negatively with $\mathrm{Co}_{2}$ emissions. Moreover, with a rise in energy consumption and exports the $\mathrm{Co}_{2}$ emissions fell showing a negative relationship. With an increase in urbanization, $\mathrm{CO}_{2}$ emissions decreased. It was suggested according to the fact that electricity consumption impacts negatively on $\mathrm{CO}_{2}$ emissions, more energyefficient technology must be adopted which not only will produce more clean energy but also $\mathrm{Cut}^{\mathrm{CO}_{2}}$ emissions.

Ahmed et al. (2017) studied the relationship between carbon dioxide emissions $\left(\mathrm{CO}_{2}\right)$ and economic growth in Croatia. Independent variables used were GDP and its square while carbon dioxide emissions as a dependant variable. The GDP coefficient had a positive sign while the GDP square varied negatively. Thus the presence of EKC was confirmed for Croatia in long run. The study suggested that the Croatian government ought to urge development and improvement to handle $\mathrm{CO}_{2}$ emissions. To get better economic growth, less effective innovations ought to be expelled from production parts with environmentally safe and harmless technologies.

Most of the researchers suggest the use of environment-friendly techniques for production in every production sector moreover promote and develop organic agriculture and the use of renewable energy instead of non-renewable energy is suggested. The analysis improves on the conventional analysis by not only using the separately analyzed impact of the growth of sectors as proxies of the composition effect, in a single model but also by incorporating additional explanatory variables such as total population, energy use, and exports of goods and services. As per our knowledge few of the previous studies used sector-wise growth including agriculture, services, and industry sectors.

\section{Data and Methodology}

This section comprises all the necessary information related to data, its collection, and the utilization of explicit methods or systems used to recognize select, process, and break down data to understand the issue. For analysis, the selection of data is very necessary and this study considers the time series data of Pakistan over the period from 1972 to 2017 which was collected from World Development Indicators provided on the official website of the World Bank Organization. The analysis of the study is done using ARDL methods of estimation followed by ARDL Bound Test, ARDL long run, ARDL Short-run, and some Diagnostic Analysis, etc. For examining the objective of the study, the following model is formulated, 
Model 1

$$
\text { Carbon Dioxide Emission }=f\left(\begin{array}{c}
\text { Agriculture Sector, } \text { Industrial Sector, } \\
\text { Services Sector, } \text { Population, Energy, Exports }
\end{array}\right)
$$

Or econometrically, it can also be written in the form of the equation as

$$
C o_{2}=\alpha+\beta_{1} R A G R+\beta_{2} R S E R+\beta_{3} R I N D+\beta_{4} P O P+\beta_{5} E N+\beta_{6} R E X P+\delta
$$

Where $\alpha$ is the intercept, $\beta_{\mathrm{i}}{ }^{\text {'s }}$ are vectors of coefficient and $\delta$ is the stochastic error term. Taking the natural $\log$ on both sides,

$$
L C o_{2}=\alpha+\beta_{1} L R A G R+\beta_{2} L R S E R+\beta_{3} L R I N D+\beta_{4} L P O P+\beta_{5} L E N+\beta_{6} L R E X P+\delta
$$

Where,

$\begin{array}{lll}\mathrm{LCo}_{2} & = & \log \text { of carbon dioxide emissions (Dependent variable) } \\ \mathrm{LRAGR} & = & \log \text { of real agriculture value-added } \\ \mathrm{LRSER} & = & \log \text { of real services value-added } \\ \text { LRIND } & = & \log \text { of real industry value-added } \\ \mathrm{LPOP} & = & \log \text { of total population } \\ \mathrm{LEN} & = & \log \text { of energy use } \\ \mathrm{LREXP} & = & \log \text { of real exports of goods and services }\end{array}$

Table 2: Description of variables

\begin{tabular}{|c|c|c|c|}
\hline Variables & Description & Measurement & Expected Relationship \\
\hline $\mathrm{Co}_{2}$ & Carbon dioxide emissions & $\left(\mathrm{Co}_{2}\right.$ emissions $)$ & Dependent variable \\
\hline $\mathrm{AGR}$ & Agriculture value-added & Rupees & Negative \\
\hline $\mathrm{IND}$ & Industry value-added & Rupees & Positive \\
\hline SER & Services value-added & Rupees & Negative \\
\hline EXP & Exports & Rupees & Pogative \\
\hline POP & Total population & Number & Positive \\
\hline EN & Energy use & $\mathrm{kg}$ & \\
\hline
\end{tabular}

\section{Results and Discussions}

\subsection{Unit Root test}

The results of table 3 reveal that $\mathrm{CO}_{2}$ Emissions $\left(\mathrm{LCO}_{2}\right)$ and population (LPOP) are uncovered as stationary at a level or $\mathrm{I}(\mathrm{O})$ and the variables obtained stationary at first difference or I(1) are agriculture sector output (LRAGR), services sector output (LRSER), industrial output (LRIND), energy use (LEN) and exports (LREXP) are stationary at the first difference I (1) so it may be decided that ARDL (Autoregressive and Distributed Lag model) will be applied for results. 
Table 3: ADF test results

\begin{tabular}{|c|c|c|c|c|c|}
\hline Variables & $\begin{array}{c}\text { Unit root } \\
\text { test in }\end{array}$ & $\begin{array}{c}\text { Test Equation } \\
\text { Included in }\end{array}$ & $\begin{array}{c}\mathrm{t}- \\
\text { Statistics }\end{array}$ & Probability & Remarks \\
\hline $\mathrm{CO}_{2}$ Emission $\left(\mathrm{LCO}_{2}\right)$ & Level & Intercept & -3.681234 & 0.0077 & $\mathrm{I}(\mathrm{O})$ \\
\hline \multirow{3}{*}{$\begin{array}{l}\text { Agriculture value } \\
\text { added (LRAGR) }\end{array}$} & \multirow{2}{*}{ Level } & Intercept & -0.817773 & 0.8043 & \multirow{3}{*}{$\mathrm{I}(1)$} \\
\hline & & Trend and intercept & -1.778940 & 0.6983 & \\
\hline & $1^{\text {st }}$ difference & Intercept & -8.110273 & 0.0000 & \\
\hline \multirow{3}{*}{$\begin{array}{l}\text { Industry value added } \\
\text { (LRIND) }\end{array}$} & \multirow{2}{*}{ Level } & Intercept & -2.409698 & 0.1448 & \multirow{3}{*}{$\mathrm{I}(1)$} \\
\hline & & Trend and intercept & -1.169922 & 0.9046 & \\
\hline & $1^{\text {st }}$ difference & Intercept & -5.011566 & 0.0002 & \\
\hline \multirow{3}{*}{$\begin{array}{l}\text { Services value added } \\
\text { (LRSER) }\end{array}$} & \multirow{2}{*}{ Level } & Intercept & -2.164038 & 0.2219 & \multirow{3}{*}{$\mathrm{I}(1)$} \\
\hline & & Trend and intercept & -1.909014 & 0.6330 & \\
\hline & $1^{\text {st }}$ difference & Intercept & -4.403979 & 0.0010 & \\
\hline Population (LPOP) & Level & Intercept & -2.994002 & 0.0434 & $\mathrm{I}(\mathrm{O})$ \\
\hline \multirow{3}{*}{$\begin{array}{l}\text { Exports of goods and } \\
\text { services (LREXP) }\end{array}$} & \multirow{2}{*}{ Level } & Intercept & -1.313825 & 0.6151 & \multirow{3}{*}{$\mathrm{I}(1)$} \\
\hline & & Trend and intercept & -1.021604 & 0.9306 & \\
\hline & $1^{\text {st }}$ difference & Intercept & -6.847167 & 0.0000 & \\
\hline \multirow{3}{*}{ Energy use (LEN) } & \multirow{2}{*}{ Level } & Intercept & -2.539455 & 0.1132 & \multirow{3}{*}{$\mathrm{I}(1)$} \\
\hline & & Trend and intercept & 0.520892 & 0.9991 & \\
\hline & $1^{\text {st }}$ difference & Intercept & -5.012538 & 0.0002 & \\
\hline
\end{tabular}

\subsection{ARDL Bounds Test}

Table 4 shows the results of the ARDL bound test along with calculated and critical values. In the table, the calculated value of the F-statistic is 6.293477 which is greater than the value of upper bound critical value at 1 percent so it may be concluded that there exists a long-run/ cointegrating relationship between the variables.

Table 4: Result of the ARDL bounds test

\begin{tabular}{|c|c|c|}
\hline Test Statistics & Value & K \\
\hline F-statistic & 6.293477 & 6 \\
\hline \multicolumn{3}{|c|}{ Critical Value Bounds } \\
\hline Level of Significance & Lower Bound & Upper Bound \\
\hline $10 \%$ & 2.1230 & 3.2324 \\
\hline $5 \%$ & 2.4512 & 3.6121 \\
\hline $2.5 \%$ & 2.7504 & 3.9932 \\
\hline $1 \%$ & 3.1522 & 4.4344 \\
\hline
\end{tabular}

Null Hypothesis: long-run relationship does not exist

\subsection{ARDL Long-run}

ARDL long run results are provided in table 5 in which names of variables are shown in the $1^{\text {st }}$ column, coefficient values are given in the $2^{\text {nd }}$ column, column 3 gives values of standard error, and column 4 shows the values of t-statistic while the $5^{\text {th }}$ column gives the probability values.

The agriculture sector output is inversely related to $\mathrm{Co}_{2}$ emissions. This may be since the agriculture sector is less polluting as compared to the manufacturing and industrial sector in Pakistan. 
Moreover, cultivation of crops involves more plantation and plants photosynthesize through which they absorb $\mathrm{CO}_{2}$ from the atmosphere which in turn reduces $\mathrm{CO}_{2}$ emission from the environment. This result is also reached by Jebli and Youssef (2015). Almost, $\mathrm{Co}_{2}$ emissions will reduce by 1.55 percent due to expansion in agriculture sector output by one percent.

The industrial sector output is directly connected with $\mathrm{Co}_{2}$ emissions. The reason behind this may be the industries which are being operated using heavy machinery and the raw material which is used is composed of chemicals which are used to make synthetic products for example rubber, textile fiber, etc. The production process of industrial goods involves high carbon dioxide emissions that can be generated by the heating process or by the burning of fuel used by heavy machinery. This result is already concluded by Mulali and Ozturk (2015). Nearly, $\mathrm{Co}_{2}$ Emission will augment by 2.35 percent due to expansion in industrial sector output by one percent.

Services sector output is inversely correlated with $\mathrm{Co}_{2}$ emissions. As confirmed by Anis Omri (2018), the sign of services sector output can vary depending on the financial condition of the respective country. It is expected to be positive for the case of countries that are included in high-income earners while negative for the case of countries lying in the low-income category. This may be due to the reason that high-income countries mostly rely on the output of services and industry for enhanced growth and development as compared to low or middle-income countries. These sectors use more energy so results in high $\mathrm{Co}_{2}$ emissions. As Pakistan is a middle-income country, most of the earning potential is directed towards the services sector which requires human capital mostly so it is less polluting as compared to the industrial sector. Moreover, the findings of Fried et al (2005) also showed the same effect of services sector output with carbon dioxide emission in Austria. About, $\mathrm{Co}_{2}$ Emission will decline by 2.08 percent due to expansion in the services sector output by one percent.

\section{Table 5: Long Run Results}

\begin{tabular}{|c|c|c|c|c|}
\hline Variables & Coefficients & Standard Error & t-Statistic & Probability \\
\hline Agriculture Sector Output & -1.546971 & 0.539360 & -2.868158 & 0.0241 \\
\hline Industrial Sector Output & 2.365219 & 0.850862 & 2.779793 & 0.0273 \\
\hline Services Sector Output & -2.086130 & 1.061249 & -1.965731 & 0.0901 \\
\hline Exports & -0.910531 & 0.312817 & -2.910744 & 0.0226 \\
\hline Population & 3.771899 & 1.519850 & 2.481757 & 0.0421 \\
\hline Energy Consumption & 3.010516 & 0.567957 & 5.300607 & 0.0011 \\
\hline Constant & -14.719430 & 2.529429 & -5.819271 & 0.0007 \\
\hline
\end{tabular}

The coefficient value of exports is -0.910531 which says that with a 1 percent increase in the exports may fall $\mathrm{CO}_{2}$ emissions by 0.910531 percent. A similar result is also reached by Shahbaz et al (2014). The reason for this inverse relationship maybe that foreigners demand environment-safe products so the exports must meet the necessary safety requirements specified by ISO (international organization for standardization). Pakistan being an agrarian country mostly exports agricultural goods, the production of which contributes less to $\mathrm{CO}_{2}$ emissions. In this context, if the exports of Pakistan rise, the emission of $\mathrm{CO}_{2}$ reduces.

The probability value of population (POP) is 0.0421 which is less than 0.10 with a value of coefficient as 3.771899 which may be interpreted as with 1 percent increase in the total population of a country, $\mathrm{CO}_{2}$ emissions increase by 3.771899 percent. This shows that the growth total population (POP) is directly related to $\mathrm{CO}_{2}$ emissions. This result is also reached by Cole and Neumayer (2004). The justification behind the positive relationship between total population (POP) and carbon dioxide 
emission $\left(\mathrm{CO}_{2}\right)$ might be that with the increase in the population of a country the demand for more facilities (e.g. construction of new houses, transportation facilities, etc) increase, the production of which requires more energy which in turn increases the $\mathrm{Co}_{2}$ emissions.

The value of the coefficient of energy use is 3.010516 which says that with a 1 percent rise in the growth of energy use (EN) $\mathrm{Co}_{2}$ emissions increase by almost 3.010516 percent. This means that energy use in terms of growth is positively linked to $\mathrm{Co}_{2}$ emission. This may be due to the reason that to increase the real output more energy is needed and using more energy results in more carbon dioxide emissions $\left(\mathrm{CO}_{2}\right)$. This result was also reached by Apergis and Payne (2010).

\subsection{ARDL Short-run}

In the short-run results of ARDL, COINTEQ is the important term that is associated with a negative sign and probability value less than 0.10 presenting convergence towards long-run results in a response of any problem/ disequilibrium in short-run results or scenario.

Table 6: ARDL Error Correction Model

\begin{tabular}{|c|c|c|c|c|}
\hline Variables & Coefficients & Standard Errors & T-Statistic & $\begin{array}{c}\text { Probability } \\
\text { values }\end{array}$ \\
\hline $\mathrm{D}(\mathrm{LCO} 2(-1))$ & -0.745067 & 0.399480 & -1.865093 & 0.1044 \\
\hline $\mathrm{D}(\mathrm{LCO} 2(-2))$ & -0.346371 & 0.375108 & -0.923390 & 0.3865 \\
\hline $\mathrm{D}(\mathrm{LCO} 2(-3))$ & 0.260936 & 0.235381 & 1.108569 & 0.3042 \\
\hline D(LRAGR) & -0.724743 & 0.217750 & -3.328332 & 0.0126 \\
\hline D(LRAGR(-1)) & -0.110128 & 0.153016 & -0.719718 & 0.4950 \\
\hline D(LRIND) & 1.005053 & 0.344933 & 2.913767 & 0.0225 \\
\hline D(LRIND $(-1))$ & -0.423421 & 0.191561 & -2.210373 & 0.0628 \\
\hline D(LRIND(-2)) & -0.052264 & 0.177303 & -0.294771 & 0.7767 \\
\hline $\mathrm{D}(\operatorname{LRIND}(-3))$ & -0.224620 & 0.229353 & -0.979365 & 0.3600 \\
\hline D(LRSER) & -0.940202 & 0.466950 & -2.013498 & 0.0839 \\
\hline D(LRSER(-1)) & -0.090239 & 0.391756 & -0.230344 & 0.8244 \\
\hline $\mathrm{D}(\operatorname{LRSER}(-2))$ & 0.517712 & 0.318320 & 1.626386 & 0.1479 \\
\hline $\mathrm{D}(\operatorname{LRSER}(-3))$ & 0.919047 & 0.360270 & 2.550997 & 0.0380 \\
\hline D(LREXP) & -0.048065 & 0.053039 & -0.906236 & 0.3949 \\
\hline D(LREXP(-1)) & 0.334929 & 0.096880 & 3.457136 & 0.0106 \\
\hline $\mathrm{D}(\operatorname{LREXP}(-2))$ & 0.082952 & 0.045306 & 1.830949 & 0.1098 \\
\hline $\mathrm{D}(\operatorname{LREXP}(-3))$ & 0.199099 & 0.060975 & 3.265243 & 0.0138 \\
\hline $\mathrm{D}(\mathrm{LPOP})$ & -0.562743 & 0.625068 & -0.900291 & 0.3979 \\
\hline $\mathrm{D}(\mathrm{LPOP}(-1))$ & 0.419193 & 0.615011 & 0.681603 & 0.5174 \\
\hline D(LPOP(-2)) & -2.214296 & 0.952624 & -2.324419 & 0.0530 \\
\hline $\mathrm{D}(\mathrm{LPOP}(-3))$ & -2.946230 & 0.776310 & -3.795172 & 0.0068 \\
\hline D(LEN) & 1.554827 & 0.363828 & 4.273522 & 0.0037 \\
\hline $\mathrm{D}(\operatorname{LEN}(-1))$ & 0.388663 & 0.342927 & 1.133371 & 0.2944 \\
\hline $\mathrm{D}(\operatorname{LEN}(-2))$ & -0.360898 & 0.366863 & -0.983739 & 0.3580 \\
\hline $\mathrm{D}(\operatorname{LEN}(-3))$ & -0.760775 & 0.379938 & -2.002368 & 0.0853 \\
\hline CointEq(-1) & -1.022311 & 0.359600 & -2.842913 & 0.0249 \\
\hline \multicolumn{5}{|c|}{ Cointeq $=$ LCO2 $-(-1.5470 *$ LRAGR $+2.3652 *$ LRIND $-2.0861 *$ LRSER } \\
\hline \multicolumn{5}{|c|}{$-0.9105 *$ LREXP $+3.7719 *$ LPOP $+3.0105 *$ LEN -14.7194$)$} \\
\hline
\end{tabular}




\subsection{Diagnostic Statistics}

After analyzing the econometric results, it is necessary to check the validity of the results. For this purpose there is a need to apply various diagnostic statistics which are given below;

1) Serial Correlation LM test

2) Normality Test

3) Ramsey Reset Test

4) CUSUM and CUCUMSQ Test

\subsubsection{Serial Correlation test}

Table 7 provides the results of the Breusch-Godfrey Serial Correlation LM test to identify the issue of autocorrelation enlightening 0.702410 as the value of F-statistics with 0.4341 as its probability value. It indicates that there is no problem of autocorrelation found in the given model.

Table 7

\begin{tabular}{|c|c|c|c|}
\hline Test Statistic & Probability & Test Statistic & Probability \\
\hline F-statistic & 0.702410 & Prob. F(1,6) & 0.4341 \\
\hline Obs*R-squared & 4.191984 & Prob. Chi-Square(1) & 0.1406 \\
\hline
\end{tabular}

\subsubsection{Normality Test}

Figure 1 shows the results of the Jarque-Bera normality test to understand the normality of residuals of the model. The results of the normality test show that the probability value is 0.817931 which is greater than 0.10 which confirms that residuals of the regression model are normally distributed.

Figure 1: Normality Test

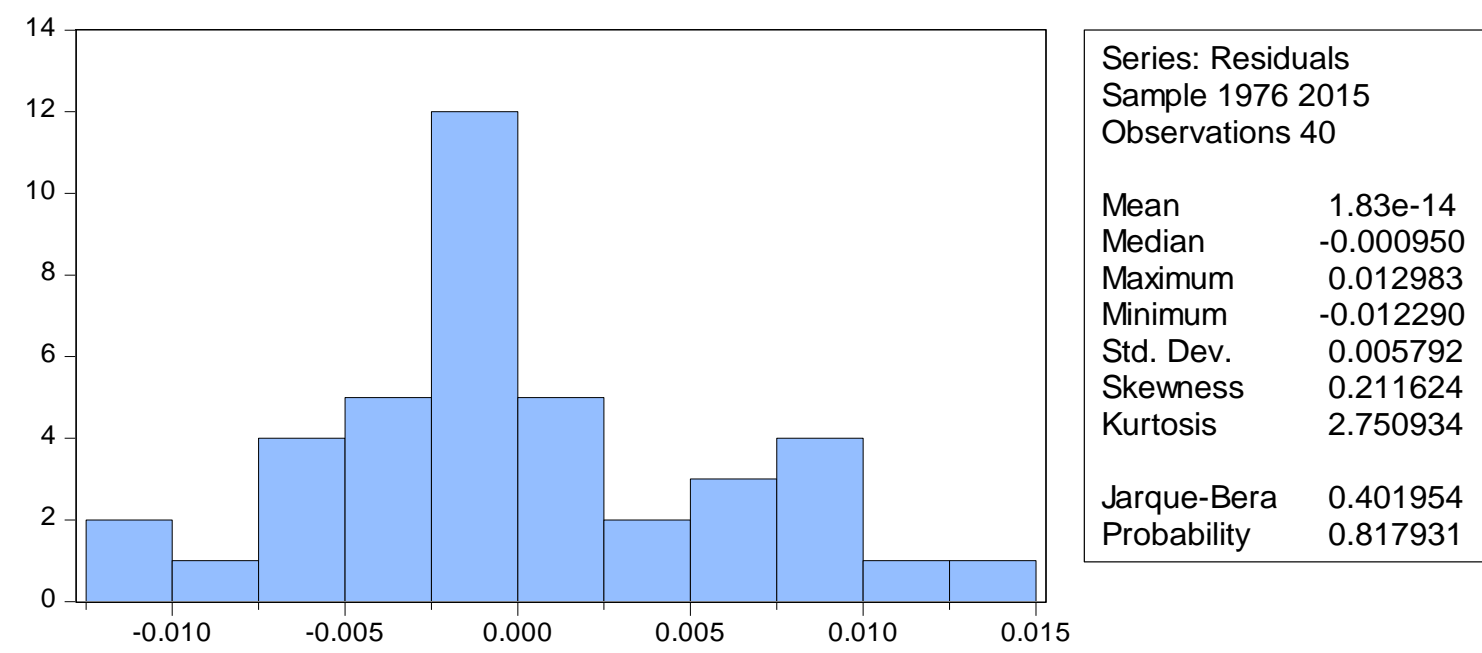

\subsubsection{Model Specification Test}

Table 8 displays the outcome of the Ramsey Reset Test conducted for checking the correct specification of the model. The F- statistics of the Ramsey Reset Test is 0.070217 along with the probability value of 0.7999 which verifies that our ARDL model is correctly specified. 
Table 8: Ramsey RESET rest

\begin{tabular}{|c|c|c|c|}
\hline Test Statistic & Values & Degrees of freedom & Probability values \\
\hline T-stat. & 0.264986 & 6 & 0.7999 \\
\hline F-stat. & 0.070217 & $(1,6)$ & 0.7999 \\
\hline
\end{tabular}

\subsubsection{Dynamic Stability Test}

Figures 2 and 3 report CUSUM-Cumulative sum of recursive residuals and CUSUMSQCumulative sum of squares of recursive residuals respectively which examine the dynamic stability of ARDL models. It can be seen clearly that the lines fall between the critical bound lines depicted by redcolored lines in both the graphs. This shows that the model is dynamically stable.

\section{Figure 2: CUSUM Test}

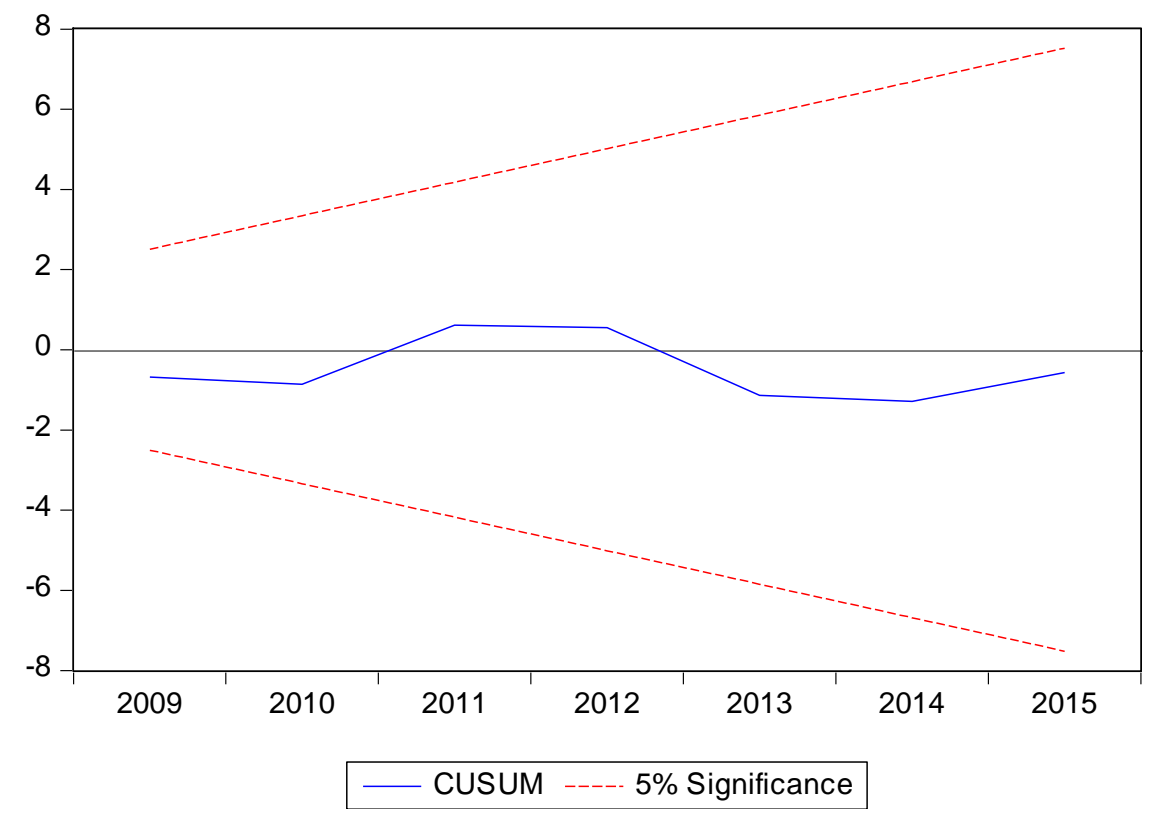

Figure 3: CUSUMSQ Test

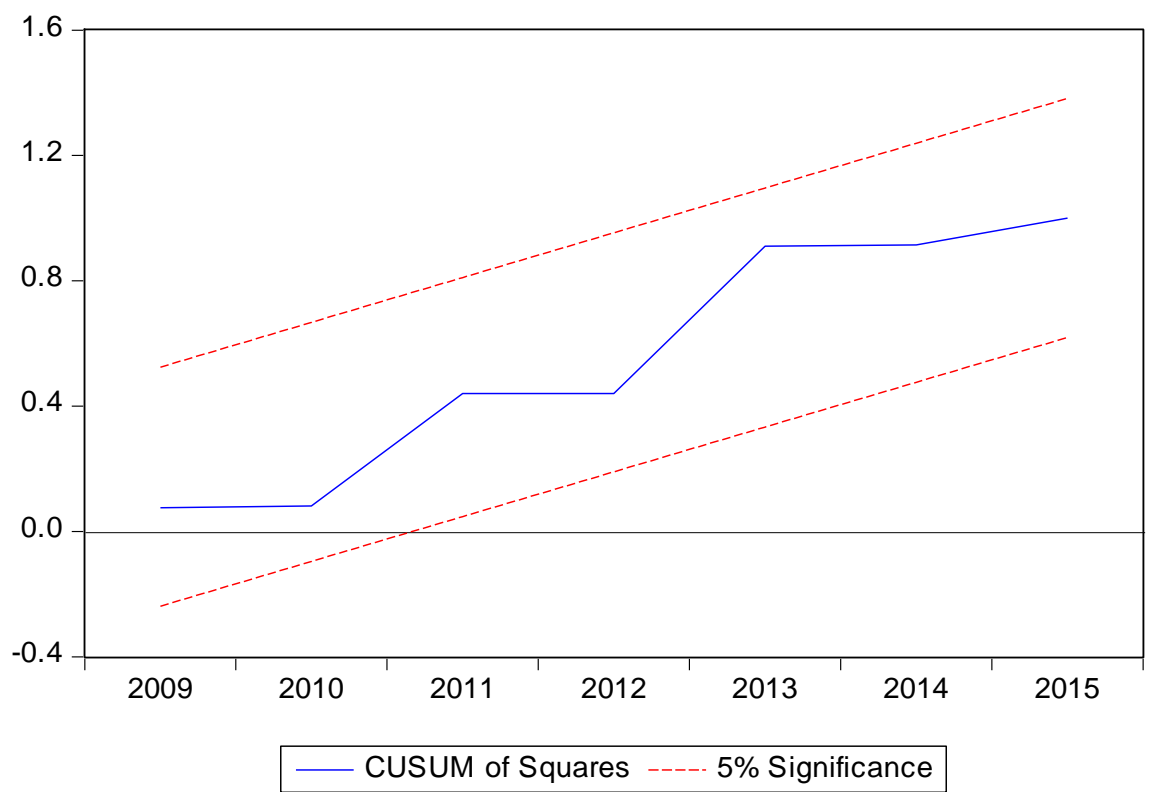




\section{Conclusions and Policy Implications}

To check the impact of sectoral growth on environmental degradation in Pakistan, time-series data is used over the period from 1972 to 2017 which is obtained from World Development Indicators (WDI). The data is carried out by econometric analysis consisting of ARDL testing approach and the model is obtained in the log-log form to account for elasticities.

ADF-Unit root test is applied to check the stationarity of variables which furnishes that $\mathrm{CO}_{2}$ emission $\left(\mathrm{LCO}_{2}\right)$ and population (LPOP) are stationary at a level or I(o) while agriculture sector output (LRAGR), services sector output (LRSER), industrial output (LRIND), energy use (LEN) and exports (LREXP) are stationary at first difference or I(1) so the technique used here is ARDL (Autoregressive distributed lag approach).

ARDL Bounds test validates the evidence of the existence of long-run relationship/ Cointegration among variables. The results of ARDL long-run state that the elasticities of $\mathrm{Co}_{2} \mathrm{Emission}$ about agriculture value-added, industry value-added, services value-added, exports, population, and energy use are $-1.55,2.36,-2.09,-0.91,3.77$, and 3.01 respectively. The ARDL long-run result points out that Industry value-added, population, and energy use have been discovered as increasing Carbon Dioxide Emissions $\left(\mathrm{CO}_{2}\right.$ Emissions) in the long run while agriculture value-added, services value-added, and exports are negatively related to $\mathrm{Co}_{2}$ Emissions in Pakistan. Diagnostic analysis of the model authenticates that ARDL results are not having any problem of Autocorrelation, Model Misspecification, Abnormality of residuals, Dynamic instability of the model.

Keeping in view the results it is suggested that Pakistan needs to make its industry sustainable by replacing the old capital stock with new and energy-efficient capital. Moreover, it is favorable to replace less efficient technologies with environmental-friendly technologies to make the production process less polluting. Pakistan should also promote the use of organic agriculture which is more environmentally friendly. Promoting Agriculture would not only help in increasing the development of renewable energy but would also reduce $\mathrm{CO}_{2}$ emissions. Promotion of environment-friendly products meeting the international standards produced via environment safe procedures using the latest technology and enhancing the service sector growth using appropriate policies is suggested.

\section{References}

Acar, S., and Tekce, M. (2014). Economic Development and Industrial Pollution in the Mediterranean Region: A Panel Data Analysis. Topics in Middle Eastern and African Economies, 16 (1), 65 - 96.

Ahmad, N., Du, L., Lu, J., Wang, J., Li, H. Z. and Zaffar, M. (2017). Modelling the CO2 emissions and economic growth in Croatia: Is there any environmental Kuznets curve?, Energy, 123, 164 - 172.

Ang, J.B., (2007). CO2 emissions, energy consumption, and output in France. Energy Policy, 35, 47724778.

Asumadu-Sarkodie, S., \& Owusu, P. (2016a). The casual nexus between child mortality rate, fertility rate, GDP, household final consumption expenditure, and food production index. Cogent Economics \& Finance, 4(1), 1191-1985

Asumadu-Sarkodie, S., \& Owusu, P. A. (2016b). Feasibility of biomass heating system in Middle East Technical University, Northern Cyprus Campus. Cogent Engineering, 3(1), 1134304

Asumadu-Sarkodie, S., \& Owusu, P. A. (2016c). The potential and economic viability of solar photovoltaic power in Ghana Energy Sources, Recovery, Utilization, and Environmental Effects, 38, 709-716. 
Asumadu-Sarkodie, S., \& Owusu, P. A. (2016d). The relationship between carbon dioxide and agriculture in Ghana: A comparison of VECM and ARDL model. Environmental Science and Pollution Research, 23, 10968-10982.

Asumadu-Sarkodie, S., \& Owusu, P. A. (2016e). Recent evidence of the relationship between carbon dioxide emissions, energy use, GDP and population in Ghana: A linear regression approach. Energy Sources, Economics Planning, and Policy.

Azam, M., Khan, A. Q., Abdullah, H. B., \& Qureshi, M. E. (2016). The impact of CO2 emissions on economic growth: Evidence from selected higher $\mathrm{CO}_{2}$ emissions economies. Environmental Science and Pollution Research, 23, 6376-6389.

Breusch, T. S., \& Pagan, A. R. (1979). A Simple Test for Heteroscedasticity and Random Coefficient Variation. Econometrica.

Cole, M. A. and Neumayer, E. (2004). Examining the Impact of Demographic Factors On Air Pollution. Population and Environment, 26 (1), 5 - 21.

Costantini, V., Monni, S., 2006. Environment, human development, and economic development. Ecol. Econ., 64, 867-880.

Dickey, David A., and Wayne A. Fuller. 1979. Distribution of the estimators for autoregressive time series with a unit root. Journal of the American Statistical Association, 74, 427-431.

Ezzati, M., Singer, B.H., Kammen, D.M., 2001. Towards an integrated framework for development and environmental policy: the dynamics of Environmental Kuznets Curves. World Development, 29 (8), 1421-1434.

Grossman, Gene M., and Alan B. Krueger. 1991. Environmental Impacts of a North American Free Trade Agreement. Working Paper 3914. National Bureau of Economic Research.

Jarque, C., Bera, A. (1980). Efficient tests for normality homoscedasticity and serial independence of regression residuals. Econometric Letters, 6, 255-259.

Jarque, C., Bera, A., (1987). A test for normality of observations and regression residuals. International Statistical Review, 55, 163-172.

Kahuthu, A., (2006). Economic Growth and Environmental Degradation in a Global Context. Environment, Development and Sustainability, 8(1), pp. 55-68.

Komen, R., Gerking, S., Folmer, H., 1997. Income and environmental R\&D: empirical evidence from OECD countries. Environment and Development Economics, 2, 505 - 515.

Mol, A.P.J., Spaargaren, G., Sonnenfeld, D.A., 2009. Ecological modernisation: three decades of policy, practice and theoretical reflection. In: Bemmann, M., Metzger, B., von Detten, R. (Eds.), Ökologische Modernisierung. Zur Geschichte and Gegenwart eines Konzepts in Umweltpolitik und Sozialwissenschaften. Frankfurt, Campus Verlag, pp. 35-66.

Munir, S. and Khan, A. (2014). Impact of Fossil Fuel Energy Consumption on $\mathrm{CO}_{2}$ Emissions: Evidence from Pakistan (1980-2010). The Pakistan Development Review, 53(4), 327 - 346.

Narayan, P.K. (2004). Fiji's tourism demand: the ARDL approach to cointegration. Tourism Economics, $10(2), 193-206$.

Ozcan, B. (2013). The nexus between carbon emissions, energy consumption and economic growth in Middle East countries: A panel data analysis. Energy Policy, 62, 1138-1147

Pesaran, M.H., Pesaran, B. (1997). Working with Microfit 4.o: Interactive Econometric Analysis, United Kingdom: Oxford University Press

Pesaran, M.H., Shin, Y., Smith, R.J. (2001). Bounds Testing Approaches to the Analysis of Level Relationships. Journal of Applied Econometrics, 16 (3), 289-326.

Ramsey, J. B. (1969). Test for Specification error in Classical Linear Least Squares Regression Analysis. Journal of the Royal Statistical Society, B.31, 350-371.

Sbia, R., Shahbaz, M. and Hamdi, H. (2014). A contribution of foreign direct investment, clean energy, trade openness, carbon emissions and economic growth to energy demand in UAE. Economic 
Modelling, 36, 191-197.

Vukina, T., Beghin, J.C., Solakoglu, E.G., 1999. Transition to markets and the environment: effects of the change in the composition of manufacturing output. Environment and Development Economics, 4 (4), $582-598$.

X. Liu and Z. Wang, (2009). The CUSUM control chart for the autocorrelated data with measurement error. Chinese Journal of Applied Probability and Statistics, 25 (5), 461-474.

Z. Wu, S. Zhang, and P. Wang, (2007). A CUSUM scheme with variable sample sizes and sampling intervals for monitoring the process mean and variance. Quality and Reliability Engineering International, 23 (2), 157-170. 